UDC 631.164:657.421.3

JEL Classification: Q1

DOI: https://doi.org/10.32317/2221-1055.201909040

\author{
O.V. ZAKHARCHUK, doctor of economic sciences, senior research fellow \\ T.V. MATSYBORA, candidate of economic sciences, senior researcher fellow \\ $V . V$. NECHYTAILO, candidate of economic sciences \\ V.O. ANTONENKO, post-graduate student*
}

\title{
Valuation of non-material assets in agriculture
}

The purpose of the article is to explore existing views on methodological approaches to the valuation of non-material assets through a prism of the development of intellectual property and capitalization of agricultural enterprises in modern conditions.

Research methods. Dialectical method of scientific cognition, analysis and synthesis, systematic generalization (generalization of approaches to the valuation of non-material assets and drawing conclusions), methods of abstraction, comparison (when estimating the initial and fair value of a plant variety) were used in the research process.

Research results. Approaches to the valuation of non-material assets through a prism of the development of intellectual property and capitalization of agricultural enterprises were considered and generalized. The method of estimating value of plant variety was substantiated; the proposed method of determining an initial and fair value of a plant variety was based on the rating of each object.

Elements of scientific novelty. Based on the generalization of approaches to valuation of non-material assets, a method for estimating value of a plant variety based on establishing the rating of variety, its volume and term of use, and agreed percentage of royalties was proposed.

Practical significance. Conclusions, suggestions and practical recommendations, as well as the proposed methodology for estimating value of a plant variety, when applied in practice, can significantly change the relationship between plant selection breeders, seed variety owners and seed producers, and provide fair financial calculations, which would give a new impetus for the development of national selection. Figs.: 3. Refs.:20.

Keywords: non-material assets; non-material assets in agriculture; valuation of non-material assets; identified tangible assets; unidentified tangible assets; intellectual property; object of intellectual property; estimation of value of plant variety.

Zakharchuk Oleksandr Vasylovych - doctor of economic sciences, senior research fellow, head of the department of investment, material and technical ensuring, National Scientific Centre "Institute of Agrarian Economics" (10, Heroiv Oborony st., Kyiv)

E-mail: zahar-s@ukr.net

ORCID iD https: //orcid.org/0000-0002-1734-1130

Matsybora Tetiana Viktorivna - candidate of economic sciences, senior researcher fellow, leading research fellow of the department of investment, material and technical support, National Scientific Centre "Institute of Agrarian Economy" (10, Heroiv Oborony st., Kyiv)

E-mail: tatyk@ukr.net

Nechytailo Veronika Volodymyrivna - candidate of economic sciences, senior researcher fellow of the department of investment, material and technical support, National Scientific Centre "Institute of Agrarian Economy" (10, Heroiv Oborony st., Kyiv) E-mail: nika.nechytailo@gmail.com

Antonenko Vasyl Oleksandrovych - post-graduate student of the department of investment, material and technical support, National Scientific Centre "Institute of Agrarian Economy" (10, Heroiv Oborony st., Kyiv)

E-mail: vasyl.antonenko@minagro.gov.ua

Scientific problem. In the modern practice of innovation-investment activity and accounting at enterprises, in accordance with the valuation methods there are used a number of types of fixed assets value: initial, revalued, residual (balance), market, fair, etc. In the diagnosis of investment attractiveness and cre-

\footnotetext{
* Scientific supervisor - T.V. Matsybora, candidate of economic sciences, senior researcher fellow.

(c) O.V. Zakharchuk, T.V. Matsybora, V.V. Nechytailo, V.O. Antonenko, 2019
}

ditworthiness of enterprises, the valuation of non-material assets should be carried out at the market value of objects using standards and methods of expert appraisal of the property. Organizational and methodological bases of expert evaluation of non-material assets, the result of which is the calculation of their market value, are determined by a number of regulatory acts $[7,13,14,15,16]$. Principal provisions for the assessment of fixed assets are substantiated by International Valuation Standards and the Standards of Valuation 
of Individual Independent Professional Appraisers' Organizations [10, 18, 19]. However, we consider it necessary to specify the methodological provisions for valuation of non-material agricultural assets in accordance with the specifics of the industry, the features of such objects and their market.

Each market entity a market economy should have available capital estimated at fair value: monetary capital in the form of bank assets and securities; production capital the form of monetary valuation of real estate (buildings, machinery and equipment, land) and inventories; commodity capital in the form of the aggregate monetary valuation of produced but not sold products; intellectual capital in the form of property rights to objects (invention, utility model, industrial design, trademark for goods and services, plant variety, brand name, computer programs, databases, scientific and technical information).

Analysis of recent research and publications. Theoretical and methodological basis of the research on the valuation of non-material assets of agricultural enterprises are the main provisions outlined in the works of national and foreign experts, in particular: I.T. Balabanov [1], R. Barr [2], I. Bernard [3], S.L. Brue [6], Jean-Claude Colley [3], M.I. Gerun [8, 18], V.S. Kropyvko [17], V.G. Lisniak [18],
K.R. McConnell [6], M.G. Mikhailov [9], M.M. Mogilova [8, 11, 18], G.M. Pidlisetskiy [8, 18, 20], O.I. Rudnyk-Ivashchenko[17], H. Seidel [4], R. Temen [4], O. V. Zakharchuk [5, 12], V.M. Zhuk [18] and others.

The purpose of the articleis to explore existing views on methodological approaches to the valuation of non-material assets through a prism of the development of intellectual property and capitalization of agricultural enterprises in modern conditions.

Research results. Non-material assets are specific non-tangible assets that are used for a long time and can generate income. In accordance with clauses 7-11 of the Procedure for expert evaluation of non-material assets, the following objects are included (Figure 1).

Non-material assets are divided into identified and unidentified. In accounting in accordance with National Accounting Standard 8, identifiable non-material assets include nonmonetary assets that have no tangible form, can be identified and held by an enterprise for use over a period of more than one year (or an operating cycle if it exceeds one year) for production, trade, administrative purposes, or renting to others. These mainly include intellectual property rights and environmental rights. In accounting, there are the following groups of identified non-material assets (Figure 2).

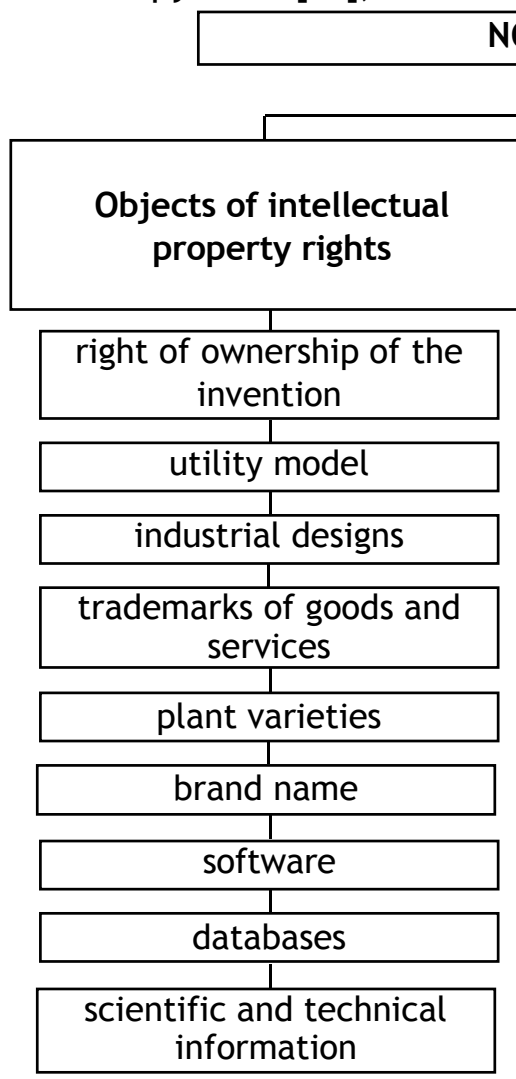
NON-MATERIAL ASSETS OF THE ENTERPRISE

\begin{tabular}{|c|}
\hline $\begin{array}{c}\text { Objects of intellectual } \\
\text { property rights }\end{array}$ \\
\hline $\begin{array}{c}\text { right of ownership of the } \\
\text { invention }\end{array}$ \\
\hline utility model \\
\hline industrial designs \\
\hline trademarks of goods and \\
services \\
\hline 1 \\
\hline plant varieties \\
\hline brand name \\
\hline software \\
\hline databases \\
\hline scientific and technical \\
information
\end{tabular}

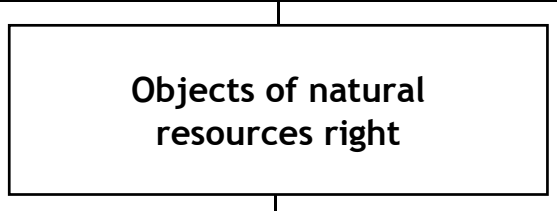

right to use land, mineral, geological and other resources of the environment and information about them

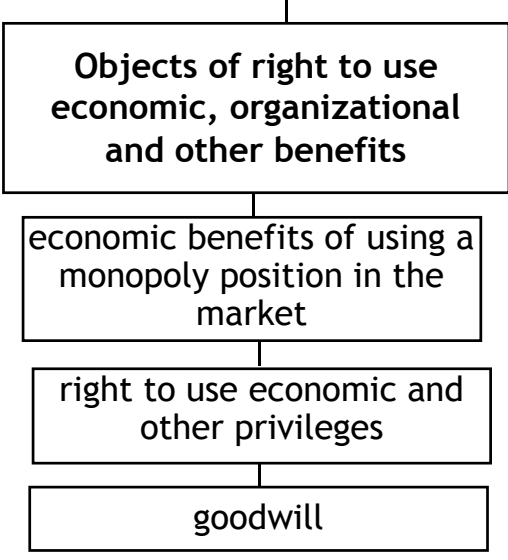

Figure 1. Classification of non-material assets of enterprise

Source: [13]. 
Unidentified non-material assets include a special type of non-material assets - goodwill, which occurs when a business is merged or as a result of an acquisition of another enterprise. Goodwill is the excess of the cost of the acquisition over the share of the buyer at fair value of the acquired identifiable assets and liabilities at the acquisition date. Negative goodwill is the excess of the cost of the buyer's share at the fair value of the identified assets acquired and liabilities over the acquisition cost at the acquisition date. Accounting for goodwill is regulated by National Accounting Standard 19. While privatization expert evaluation only be positive goodwill. In privatization, goodwill is only a subject to expert evaluation.

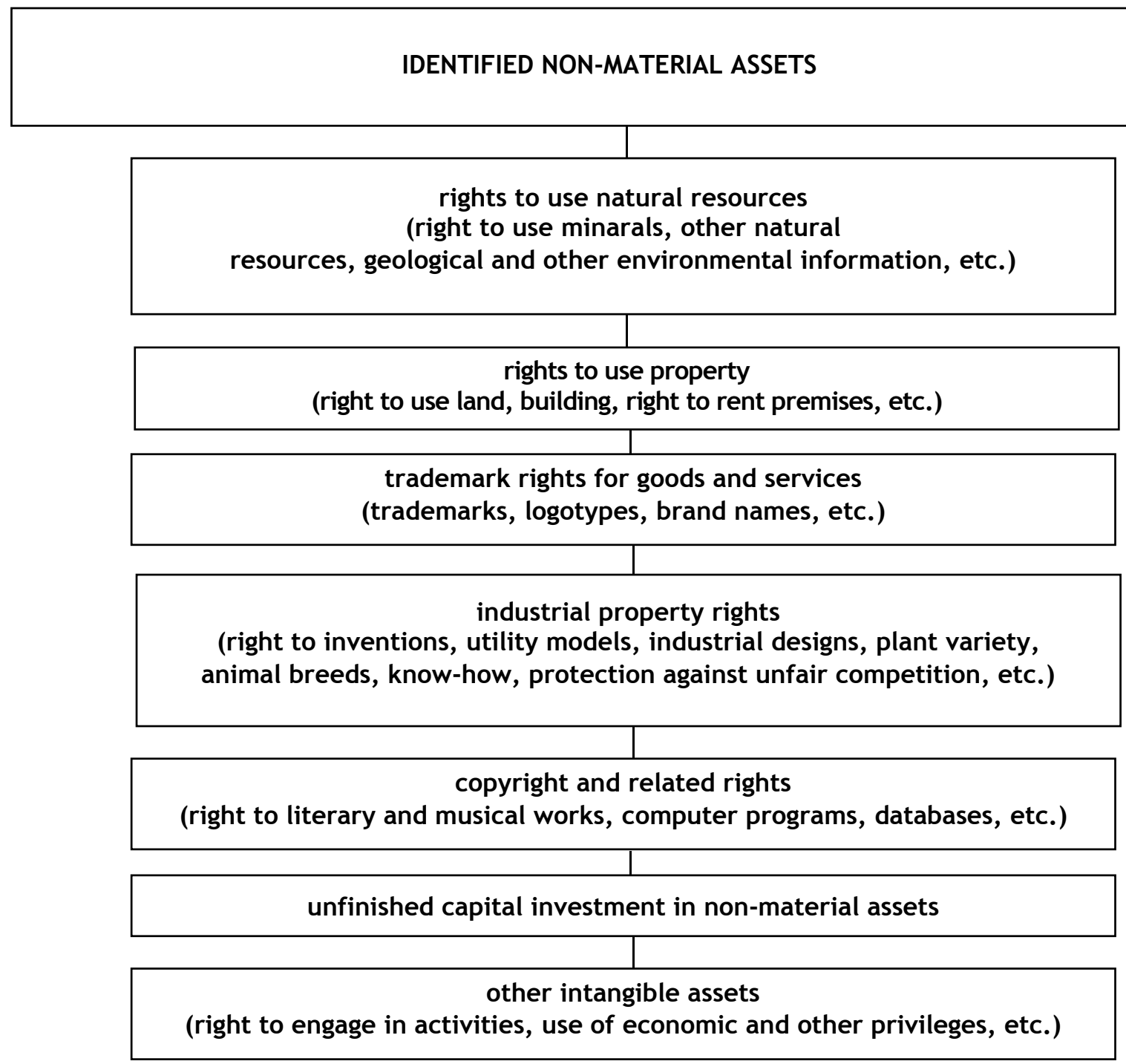

Figure 2. Classification of identified non-material assets of the enterprise

Source: [13].

The primary (revalued), residual value and accrued amount of accumulated depreciation of non-material assets are recorded in inventory accounting cards and in accounts 12 "Non-material assets" and 133 "Depreciation of non-material assets".

In agricultural enterprises, non-material assets are subject to valuation only if there are documents certifying the rights of the enterprise to them. In valuating the assets of an enterprise, all non-material assets that are accounted for on the balance sheet and those not included in the balance sheet are taken into account.

Among the valuation types used in the valuation activity, only a few can be used in the valuation of non-material assets, subject to certain specific conditions. For the valuation of non-material assets, it is possible to take the market value, replacement cost, cost of reproduction, residual cost of replacement (reproduction), cost of use, investment value, special value. Insurance and mortgage values are practically not used for non-material assets. 
Non-material assets, which are not reflected in accounting, are identified and measured in an independent valuation process by object, using cost, income and comparative approaches. An income approach is considered essential for determining the value of intellectual property rights. Cost and comparative methods can be used to supplement it.

A comparative approach can be applied only in the conditions of a developed market for intellectual property rights and other nonmaterial assets, if those objects are subject to sale and purchase in an active market. This approach is practically not applicable in this field, except for the assessment of rights to computer programs.

The cost approach can be used as a complement to the income approach (if it is not an evaluation for accounting purposes). The cost approach is applied to non-material assets created by right holders and those for which there is no active market (research and development design works, special purpose software, etc.).

Depending on what documentation confirming the cost of creation the object can be provided by the right holder, the appraiser chooses the procedure that best suits the particular situation:

- If the customer has a documented cost estimate, the appraiser can apply the cost of reproduction method;

- if no cost estimate is available, it may be drawn up by the appraiser within the scope of the replacement cost method.

The use of any cost approach procedure must result in the determination of wear and tear caused by factors of functional and economic aging.

The basis of the cost-of-reproduction method is the equivalence of the value of the intellectual property rights with the cost of creating them with a reasonable profit margin. Such reproduction implies a full copy of calculation of the object of evaluation and the cost of its legal protection. Determined by using this method, the cost-of-reproduction is defined as the sum of the costs required to create an exact copy of the valuation object. These costs should be calculated based on the current prices of raw material, energy, and the average industry value of the workforce of relevant qualification.

As an alternative to the actual costs estimated by the initial cost method, the cost of creating a new copy may include:
- cost of inventories and services of thirdparty organizations and individuals employed in carrying out these activities;

- costs of wages and other payments to employees directly employed to perform certain work under an employment contract;

- social payments;

- the cost of special equipment intended for use as objects of testing and research;

- depreciation of fixed assets and nonmaterial assets used during the execution of these works;

- costs for the maintenance and operation of research equipment, installations and structures, other objects of fixed assets and other property;

- general economic expenses, if they are directly related to the execution of these works;

- other costs directly related to the implementation of research, development and technological work, including the cost of testing;

- taxes and other required non-refundable payments.

When evaluating IPRs (intellectual property rights) for accounting on an enterprise balance sheet, it is possible to use the formula [8]:

where

$$
C r=A c \sum_{l=t}^{T} C i \times F i i,
$$

$\mathrm{Cr}$ - intellectual property reproduction cost;

Ac - coefficient of moral aging;

$\mathrm{Ci}$ - cost of creating an asset incurred in the $\mathrm{i}$-th year;

Fii - index factor that takes into account changes in price indices of the $i$-th year to the current date (assessment date);

$t$ - initial year of the calculation period;

$\mathrm{T}$ - final year of the calculation period.

The coefficient of moral aging (Ac) is calculated by the formula [8]:

$A c=1-(T a: T n)$,

where

Ta - actual (current) term of the security document;

$\mathrm{Tn}$ - the nominal (legal) term of the security document.

The costs of creating an asset in enterprise can be determined by the formula [8]:

$C=C w+C s p+C i+C f o+C t e+C s e+C d+C m r e+C g+C p+C o+C t p$, where

C - cost of creating non-material asset in enterprise; 
CW - wage costs and other payments to employees directly engaged in the implementation of research and development work;

Csp - social payments;

$\mathrm{Ci}$ - the cost of inventories used in the performance of these works;

Cfo - factory overhead costs;

Cte - travel expenses of performers;

Cse - the cost of special equipment for research and testing;

Cd - depreciation of fixed and non-material assets used in carrying out these works;

Cmre - costs for the maintenance and operation of research equipment, installations and structures, other fixed assets;
$\mathrm{Cg}$ - general economic expenses directly related to the execution of these works;

$\mathrm{Cp}$ - costs of patenting;

Co - other expenses, including the services of third parties involved in the creation of the asset;

Ctp - taxes and other mandatory payments on the cost of creating the asset.

When calculating the cost of reproduction of different types of non-material assets, it may include different costs for the creation of the asset and apply different ratios of adjustment in order to align the current value. The main methods of valuation of nonmaterial assets are presented in Figure 3.

METHODS OF VALUATION OF NON-MATERIAL ASSETS

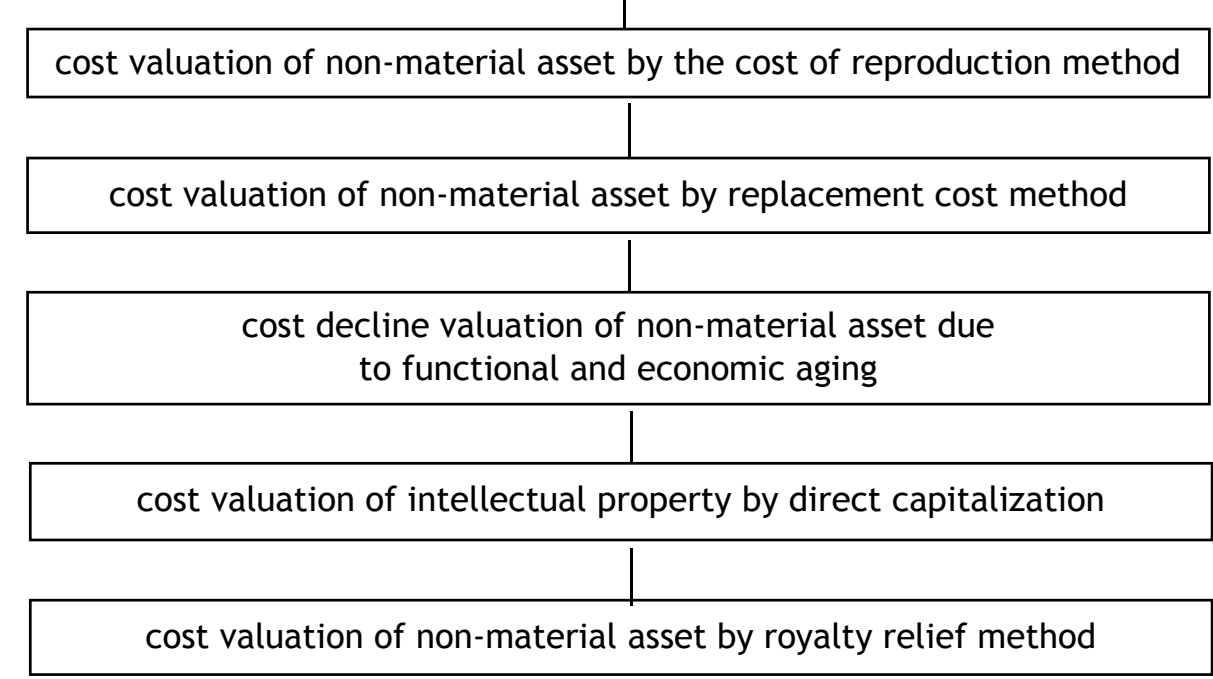

Figure 3.Valuation of non-material assets of enterprise

Source: [7].

In the development of varietal plant resources in the period of stabilization and increase in production of crops and ensuring food security of the country, a particularly important role belongs to the methodological base and its tools. As methods for determining the value of a variety as an intellectual property object in Ukraine are not regulated, in the practice of relationships are apply approaches, based on a complex system of compromises between the parties followed by the conclusion of licensing agreements that enable reached arrangements get official status.

Under conditions, when the capitalization of plant varieties becomes an important factor in the growth of indicators of competitiveness, financial sustainability and investment attractiveness of agricultural enterprises, absence of the established procedure of state evaluation of the cost of plant variety impedes the process of formation and use of intellectual property on domestic and foreign varietal plant resources. Therefore, Ukraine should create the necessary methodological base for the mass introduction of scientifically based methods of valuation of plant varieties.

Due to insufficient development of these methods, the National Science Center "Institute of Agrarian Economy" has developed appropriate methodological approaches and recommendations during the process of this research, and granting official status to them would allow to establish and massively implement uniform methodological principles for the valuation of plant variety cost based on the cumulative annual economic effect that 
can be obtained or actually obtained from agricultural production, seed selection and seed production.

These scientific research results assumed that the annual economic effect of a new variety should be characterized by the total economic benefits of agricultural producers, seed breeders and producers of basic and certified seeds, and the size of this effect should be determined using two groups of methods in cases of:

- establishment of real economic effect, which is obtained by advantages in profit and price, saving of variable and conditionally fixed costs and volumes of sales of products;

- calculation of the conditional effect upon royalty relief and determination of the licensee's share in the licensee's profit.

The above methodical recommendations should be applied in cases of purchase and sale of plant varieties, contribution of variety cost into authorized (statutory) capital of the enterprise, input of the variety as an intellectual property object on the balance of the organization, resolving property disputes on the variety in court, making management and investment and other decisions.

In the process of valuating the cost of the variety, the provisions of the following legislative and regulatory acts of Ukraine should be followed:

- Law of Ukraine "On Protection of Rights to Varieties of Plants" of 21.04.1993 № 3116XII as amended on 17.01.2002;

- Law of Ukraine "On seeds and planting material" of 26.12.2002 No. 411-IV as amended on October 2, 2012 No. 5397-VI;

- International Accounting Standard 38 (IAS 38). Intangible assets, IASB International Standard as of 01.01.2012;

- Methods of valuation of property rights of intellectual property, approved by the Order of the State Property Fund No. 740 dated 25.06.2008, registered at the Ministry of Justice of Ukraine dated 06.08.2008 under No. 726/15417;

- National Standard No. 1 "General Principles of Property and Property Rights Valuation", approved by the Resolution of the Cabinet of Ministers of Ukraine Resolution of September 10, 2003 under No. 1140;

- National Standard No. 4 "Valuation of Proprietary Rights of Intellectual Property", approved by Resolution of the Cabinet of Ministers of Ukraine dated 03.10.2007 No. 1185;
- Procedure for determining the appraised value of intellectual property objects which are under state ownership or created (acquired) by state funds for accounting purpose, approved by Order of the State Property Fund of 31.12.2005 No. 3162;

- Regulation (standard) of accounting "Non-material assets" 8, approved by the Order of the Ministry of Finance of Ukraine of October 18, 1999 No. 242, registered by the Ministry of Justice of Ukraine on November 2, 1999 under No. 750/4043.

In order to prepare the initial information for valuation of the cost of variety as an intellectual property object, it is recommended to use the following information and its sources:

- State register of plant varieties suitable for distribution in Ukraine. List of genera and species of plants, the varieties of which are being examined for suitability for distribution and compliance with the criteria of difference, uniformity and stability in the institutions of examination of the state system of protection of rights for plant varieties;

- State register of producers of seeds and planting material;

- statistics on the actual level of the average monthly wage in Ukrainian economy sectors in previous years;

- the amount of the minimum wage at the beginning of the year;

- consumer price indices for the last three years;

- the cost of material and technical means used in expert research;

- book value of fixed assets of expertise institutions;

- cost sheet of individual institutions of expertise of the state system for the protection of plant variety rights;

- other sources and indicators.

When valuating the cost of any plant variety, the above general guidelines should be followed.

Valuation of plant variety cost.

In economic terms, the value of a plant variety is characterized by the benefit that its owner, or the owner of a part of the ownership of the variety, can (may receive) at the time of estimating that value.

The purpose of valuation of varieties in economic practice is as follows:

- contribution the value of the variety into the authorized capital of the entity; 
- input of a variety for accounting into the list of non-material assets;

- acquisition of intellectual property right to plant variety;

- sale of a license for the use of a plant variety;

- pledge of property rights of intellectual property to it by the owner of a plant variety;

- insurance of property rights of intellectual property for a variety of plants;

- determination of the starting price of the intellectual property right of the plant variety for contracts, auctions, bidding, etc.

In estimating the value of a plant variety, the following methods should be used: expenditure, analogues and income.

The expenditure method is based on the principle of substitution of the best and most efficient use of resources owing to the new variety, balance of economic size and economic expenditures sharing between the author of the variety and its user. Herewith, it is necessary:

- determine the amount of actual or regulatory (technological) costs for the creation, acquisition, introduction of plant varieties for commercial circulation and maintaining their purity;

- costs of previous periods should be aligned to the present value at the date of the valuation using the compounding method, which is the reverse of the discount method;

- determine the residual value of the variety during its use.

The income method establishes the present value of future income expected to be obtained as a result of the use or alienation of intellectual property rights of a plant variety by estimating the annual expected effect of the realization of property rights on that variety using discounting methods in years. Discount ratios to drive future cash income from a variety as an intellectual property.

The method of analogues (comparative) determines the value of a variety on the basis of actual cases of its sale in the conditions of an active and transparent market of varietiesanalogues and in the availability of information on concluded sales contracts on property rights for varieties-analogues, results of a comparative analysis of the main indicators of similar varieties of plants and adjustment of actual prices in the property rights market for plant varieties.

In assessing the value of a plant variety, there should be determined its initial or residual value, which is determined by accounting estimates or at the fair (market) price of the plant variety, the cost of creating the plant variety, as well as the price of analogue sale of intellectual property rights to plant varieties, taking into account the wear of the variety plants as an object of intellectual property. In the first stage of formation of the market of intellectual property rights for plant varieties, the method of determining the fair (market) value of the plant variety is preferred, which takes into account the future benefits of its introduction through the income of varietal seed producers. In the next stages of evaluation, the value of the plant variety is determined by the aggregate benefits of all participants in the seed selection process.

Determining the value of the plant variety by the income method is carried out in the following sequence.

1. The author of the variety, the owner of the patent, the owner of the intellectual property rights of the plant variety, the owner of the intellectual property rights to spread the plant variety, which may also be in one person, determine the amount of net income (profit) that can be obtained in the process of use of variety or property rights to it during the useful life of the plant variety.

2. The expected net income (profit) for the whole period of use of the variety shall be determined by the owner on the basis of the amount of his own expenses for the creation of the variety, actual and prospective plans of commodity crops of the variety.

3. Future annual amounts of net income (profit), which are calculated at discount factors, are brought to present value (capitalized). The determination of the discount rate and capitalization is carried out in accordance with the requirements of National Standard No. 1 "General Principles of Property and Property Rights Valuation" and National Standard No. 4 " Intellectual Property Rights Valuation".

4. The amount of income of future periods are brought to their current value, which will characterize the value of the variety for the purposes of displaying it in the accounts.

Further calculations of the book value of the plant variety are used to determine the minimum amount of royalties to the plant breeder.

The initial value of the plant variety is recorded for non-material assets in accounting and in the financial statements of the enter- 
prise (institution) in accordance with the requirements of National accounting standard 8.

The fair (market) value of a variety is determined by the transfer or granting of property rights to it on a contractual basis, the inclusion of the value of these rights in the authorized capital of the enterprise (institution), the transfer of the right to plant variety to the pledge, etc. In these cases, in accordance with paragraphs $12-16$ of National accounting standard 8 , fair value is recognized as the initial value at which the variety is valued as an non-material asset. When using a variety, its value is annually reduced by the amount of its depreciation.

In our opinion, it is neccesary to grant the status of the official method of estimating the value of a plant variety, based on the initial determination of the annual rating of each object as a numerical indicator of the benefit expected from its use, given the market (exchange) price for products received during the year per unit of volume usage.

The mentioned annual rating should be determined by the formula [17]:

$$
P_{\mathrm{a}}=P V_{\mathrm{a}} \times P_{\mathrm{p}},
$$

where

$R_{\mathrm{a}}$ - annual rating of plant variety, UAH / ha;

$P V_{a}$ - annual production volume when applying variety, $\mathrm{t} / \mathrm{ha}$;

$P_{\mathrm{p}}$ - exchange price of products, UAH / t .

The initial value in the proposed method reflects the potential cost-effectiveness of a plant variety from its use in rating parameters over the life of the security document [17]:

$$
V_{\mathrm{i}}=R_{\mathrm{a}} \times T \text {, }
$$

where

$V_{\mathrm{i}}$ - initial value of a plant variety, UAH;

$R_{\mathrm{a}}$ - annual rating of plant variety, UAH/ha;

$T$ - term of validity of the security document, year.

Determined initial value by these formulas on the basis of real economic indicators of the effectiveness of the variety of its must be reflected in accounting for non-material assets of the institution and disclosed in the financial statements in accordance with the requirements of the mentioned National accounting standard 8 .

The fair value of the variety has the character of a remuneration for the right to use them and is determined by transfer or granting of ownership rights on a contractual basis, usage of the right as a share contribution to the authorized capital of the enterprise, transfer of rights on pledge etc. In these cases, the fair value, in accordance with paragraphs 12-16 National accounting standard 8, is recognized as the initial value, at which the variety is valuated as non-material asset.

It is obvious that the amount of fair value will depend on the rating of the object, the amount and term of its use and the agreed percentage of remuneration (royalties) [17]:

$$
V_{\mathrm{f}}=R_{\mathrm{a}} \times U_{\mathrm{v}} \times T_{\mathrm{p}} \times R_{\mathrm{r}},
$$

where

$V_{f}$ - fair value of the variety, UAH;

$R_{\mathrm{a}}$ - annual rating of the variety, UAH / ha;

$U_{v}$ - planned use of the plant variety, $\mathrm{t} /$ year, ha / year;

$T_{\mathrm{p}}$ - planned term of use of the variety or the unauthorized term of its use, year;

$R_{\mathrm{r}}$ - royalty rate for the use of the plant variety.

An example of application of the proposed method is as follows:

1. Initial indicators of new variety of wheat: yield in variety research $-6.5 \mathrm{t} / \mathrm{ha}$; market (exchange) price - $5800 \mathrm{UAH} / \mathrm{t}$, validity period of the security document - 20 years, term of use according to the license agreement - 10 years on an area of 1000 ha annually, royalties - from 3\% to $5 \%$ of the harvest.

Calculation of variety rating:

$R_{\mathrm{a}}=P V_{\mathrm{a}} \times P_{\mathrm{p}}=6,5 t \times 5800 \mathrm{UAH}=37700 \mathrm{UAH}$.

Calculation of initial value of the variety:

$V_{\mathrm{i}}=R_{\mathrm{a}} \times T=37700 \mathrm{UAH} /$ year $\times 20$ years $=$ $754000 \mathrm{UAH}$.

Calculation of fair value of the variety:

$V_{\mathrm{f}}=R_{\mathrm{a}} \times U_{\mathrm{v}} \times T_{\mathrm{p}} \times R_{\mathrm{r}}=37700 \mathrm{UAH} / \mathrm{ha} \times$ 1000 ha/year $\times 10$ years $\times 0,05=18,850 \mathrm{mil} U \mathrm{UAH}$.

So, the rating of a new wheat variety in the example of calculations is $37700 \mathrm{UAH} /$ year, the initial value reflected in accounting for non-material assets - 754,0 thousand UAH, and the fair value over 10 years of using the variety in the area of 1000 ha is 18.85 million $\mathrm{UAH}$. Licensee gives licensor compensation for the right to use the new variety in the amount of UAH 18.85 million at one time as a lump sum payment, or 1885 thousand $\mathrm{UAH}$, as royalties, annually.

The above example shows that the proposed method of determining the initial and fair value of a plant variety based on the rating of each object is based on real indicators of their economic efficiency. 
This method has sufficient theoretical justification, is universal, easy to use and can be widely used for the purpose of regulating the valuation of varieties in agro-industrial production.

In the process of applying this method, first of all, the price for this variety should be determined, in market conditions, it should not be less than the cost of its creation, and should therefore take into account all costs incurred for creation variety, including the actual costs of services for variety testing. According to the calculations of authors, the amount of expenditures for cereals can range from 1.5 to 3.0 million USD. Given the fact that the funds for the entire period, during which the variety was not considered a commodity, and it becomes such only after registry into the State Register of plant varieties or after the variety is considered as promising, were frozen, that is, they did not make a profit, then the amount of expenses should be increased at least by the amount of the deposit rate during the years of their diversion from the economic turnover, which is $7-8$ years.

Various factors influence the residual value of the variety, the degree of influence of which is far from being equal. According to the research findings, the main factors of influence are:

- scientific and technological value of the plant variety, which is shown by the preservation of characteristic features during the production and sale of reproductive material to specific consumers;

- economic value of the variety, ie production, storage and sale of seeds of this variety;

- the reliability of the legal protection of the plant variety, that is, the legislative provision of guarantees of long-term validity of patents, certificates and licenses;

- real public need for licensed products, market capacity and availability of free segments.

In connection with the research, the fair and initial book value of each variety was determined on the basis of the rating of the varieties. The basis for calculating royalty is not

\section{Список бібліографічних посилань}

1. Балабанов И. Т. Основы финансового менеджмента. Как управлять капиталом? Москва : Финансы и статистика, 1995. 384 c.

2. Барр Р. Политическая экономия / пер. с фр. : [в 2 т.]. Москва : Международные отношения, 1995. Т. 1. 608 с. to determine the value of the variety through expenses incurred only, but the use of the variety for commercial sale on commodity seeds.

It is determined that the more demanded a variety is for commodity production, the higher its fair value. That is, the value increases in proportion to the number of commodity crops. Therefore, for different varieties, this value will vary significantly.

Conclusions. Research shows that the amount of royalty depends on the nature of a subject of the license agreement, volume of production and sales of products under license. Therefore, these features must be taken into account in determining the fair value of the variety. In the calculations carried out by the authors, the amount of royalties was taken to a maximum of 5 percent of the value of the possible commodity crop obtained.

Practical application of the proposed approach could significantly change the relationship between seed breeders, owners of varieties and producers of seeds and planting material in order to ensure fair financial calculations, which would give a new impetus to the development of seed selection. However, the accounting of varietal commodity and seed crops in farms of all forms of management in the first stage should be carried out through a system of mandatory statistical reporting, which should be collected every year after the end of the sowing campaign, not as it has been done so far.

In the future, an information system for plant varieties should be established in Ukraine. The function of the creation of this system could perform, for example, Seed Association of Ukraine or other independent associations. Actually, they, as independent organizations, are able to control the collection of royalties from seed buyers. Introduction of a system of payments for the use of new varieties would annually attract domestic funds in the seed selection sector of Ukraine in the amount of 2.0-2.5 billion UAH, which would significantly intensify its activity and promote more active promotion of domestic varieties to the markets of other countries.

\section{References}

1. Balabanov, I.T. (1995). Osnovyi finansovogo menedjmenta. Kak upravlyat kapitalom? [Fundamentals of financial management. How to manage capital?]. Moscow: Finansyi i statistika [In Russian].

2. Barr, R. (1995). Politicheskaya ekonomiya [Political economy]. (Vols. 1-2). (Trans. from French). Moscow: Mejdunarodnyie otnosheniya [In Russian]. 
3. Бернар И., Колли Ж.-К. Толковый экономический и финансовый словарь / пер. с фр. : [в 2 т.]. Москва : Международные отношения, 1994. Т. 1. 784 с.

4. Зайдель Х., Темен Р. Основы учения об экономике / пер. с нем. Москва : Дело ЛТД, 1994. 399 с.

5. Захарчук О. В. Економіка насінництва. Київ : «ННЦ IAE», 2015. 272 c.

6. Макконнэлл К. Р., Брю С. Л. Экономикс: принципы, проблемы и политика / пер. с 13-го англ. изд. Москва : ИНФРА, 1999. 974 с.

7. Методика оцінки майнових прав інтелектуальної власності, затверджена Наказом Фонду державного майна від 25.06.2008 р. № 740, зареєстрованого в Міністерстві юстиції України від 06.08.2008 р. за № 726/15417 (зі змінами). База даних «Законодавство України». URL : https://zakon.rada.gov.ua/laws/show/z0726-08 (дата звернення 20.08.2019).

8. Методичні рекомендації з експертної оцінки майна в підприємствах АПК / Підлісецький Г. М., Герун М. І., Могилова М. М. та ін. Київ : ННЦ ІАЕ, 2005. 220 с.

9. Михайлов М. Г. Інноваційно-інвестиційний розвиток матеріально-технічної бази аграрних підприємств. Київ : ННЦ «IAE». 2018. 334 c.

10. Міжнародні стандарти оцінки. Восьме видання. 2008 / пер. з англ. С. О. Пузенко. Київ : «АртЕк», 2008. 432 с.

11. Могилова М. М. Основні засоби сільськогосподарських підприємств: стан, оцінка, відтворення : монографія. Київ : «ННЦ ІАЕ», 2016. 404 с.

12. Насіння і садивний матеріал як об'єкт інтелектуальної власності / Захарчук О. В. та ін. Київ : ННЦ IAE, 2013. 92 c.

13. Положення (стандарт) бухгалтерського обліку "Нематеріальні активи 8", затверджене Наказом Міністерства фінансів України від 18.10.1999 р. № 242, зареєстрованого Міністерством юстиції України 02.11.1999 р. за № 750/4043 (зі змінами). База даних «Законодавство України». URL : https://zakon.rada.gov.ua/laws/show/z0750-99 (дата звернення 20.08.2019).

14. Порядок визначення оціночної вартості об'єктів права інтелектуальної власності, що перебувають у державній власності або були створені (придбані) за державні кошти, 3 метою зарахування на бухгалтерський облік, затверджений Наказом Фонду державного майна від 13.12.2005 р. № 3162 (зі змінами). База даних «Законодавство України». URL : https://zakon.rada.gov.ua/laws/show/z0479-06 (дата звернення 20.08.2019).

15. Про затвердження Національного стандарту № 4 "Оцінка майнових прав інтелектуальної власності" : Постанова Кабінету Міністрів України від 03.10.2007 р. № 1185 (зі змінами). База даних «Законодавство України» / ВР України. URL : https://zakon.rada.gov.ua/laws/show/1185-2007-\%D0\%BF (дата звернення 20.08.2019).

16. Про затвердження Національного стандарту № 1 «Загальні засади оцінки майна і майнових прав»: Постанова Кабінету Міністрів України від 10.09.2003 р. № 1440 (зі змінами). База даних «Законодавство України» / ВР України. URL : https://zakon.rada.gov.ua/laws/show/1440-2003-\%D0\%BF (дата звернення 20.08.2019).

17. Рудник-Іващенко О. І., Кропивко В. С. Оцінка вартості сорту рослин як об'єкту інтелектуальної власності. Вісник Центру наукового забезпечення АПВ Харківської області. 2013. Вип. 14. С. 287-294.

18. Стандарти з оцінки та оціночної діяльності в агропромисловому комплексі України / Підлісецький Г.М., Лісняк В.Г., Жук В. М., Могилова М. М. та ін. Київ : ВГО «ВСЕО», 2012. 240 C.

19. Стандарты оценки RICS / пер. с англ. Москва : Альпина Паблишерз, 2011. 188 с.

20. Формування ринків матеріальних ресурсів АПК / за ред. Г. М. Підлісецького. Київ : ННЦ ІАЕ, 2001. 428 с.
3. Bernard, I. \& Collie, J.-C. (1994). Tolkovyiy ekonomicheskiy $i$ finansovyiy slovar [Intelligent economic and financial dictionary]. (Vols. 1-2). (Trans. from French). Moscow: Mejdunarodnyie otnosheniya [In Russian].

4. Zaidel, H. \& Temen, R. (1994). Osnovyi ucheniya ob ekonomike [Fundamentals of the doctrine of economics]. (Trans. from German). Moscow: Delo LTD [In Russian].

5. Zakharchuk, O.V. (2015). Ekonomika nasinnytstva [Economics of seed production]. Kyiv: NNTs “IAE" [In Ukrainian].

6. McConnell, K.R. \& Brue, S.L. (1999). Ekonomiks: printsipyi, problemyi $i$ politika [Economics: principles, problems and policy]. (13 ${ }^{\text {th }}$ ed.). (Trans. from English). Moscow: INFRA [In Russian].

7. Metodyka otsinky mainovykh prav intelektualnoi vlasnosti, zatverdzhena Nakazom Fondu derzhavnoho maina vid 25.06.2008 r. \# 740, zareyestrovanogo v Ministerstvi Yustyciyi Ukrayiny vid 06.08.2008 r. za \# 726/15417 (zi zminamy) [Methodology of valuation of property rights of intellectual property, approved by the Order of the State Property Fund dated 7.06.2008, registered at the Ministry of Justice of Ukraine on 06.08.2008, under No. 726/15417]. Baza danykh "Zakonodavstvo Ukrainy". VR Ukrainy. Retrieved from: https://zakon.rada.gov.ua/laws/show/z0726-08 [In Ukrainian].

8. Pidlisetskyi, H.M., Herun, M.I., Mohylova, M.M., et al. (2005). Metodychni rekomendacii z ekspertnoi otsinky maina $v$ pidpryiemstvakh APK [Methodical recommendations for expert appraisal of property in enterprises of agro-industrial complex]. Kyiv: NNTs “IAE" [In Ukrainian].

9. Mykhailov, M.H. (2018). Innovaciino-investytsijnyi rozvytok materialno-tekhnichnoi bazy ahrarnykh pidpryiemstv [Innovative-investment development of the material and technical base of agricultural enterprises]. Kyiv: NNTs "IAE" [In Ukrainian].

10. Mizhnarodni standarty otsinky. Vosme vydannia [International valuation standards. Eighth edition]. (S.O. Puzenko, Trans.). (2008). Kyiv: “ArtEk” [In Ukrainian].

11. Mohylova, M.M. (2016). Osnovni zasoby silskohospodarskykh pidpryiemstv: stan, otsinka, vidtvorennia: monografiia [Fixed assets of agricultural enterprises: state, evaluation, reproduction: monograph]. Kyiv: NNTs "IAE" [In Ukrainian].

12. Zakharchuk, O.V., Kysil, M.I., Kropyvko, V.S., et al. (2013). Nasinnia $i$ sadivnyi material iak obiekt intelektualnoi vlasnosti [Seeds and planting material as an object of intellectual property]. Kyiv: NNTs "IAE" [In Ukrainian].

13. Nematerialni aktyvy 8: Polozhennia (standart) bukhhalterskoho obliku, zatverdzhene Nakazom Ministerstva finansiv Ukrainy vid 18.10.1999 r. \# 242, zareiestrovanoho Ministerstvom Yustytsii Ukrainy 02.11.1999 r. za \# 750/4043 (zi zminamy) [Non-material assets 8: Regulation (standard) of accounting, approved by the Order of the Ministry of Finance of Ukraine dated 18.10.1999 No. 242, registered by the Ministry of Justice of Ukraine on 2.11.1999 under No. 750/4043]. Baza danykh "Zakonodavstvo Ukrainy". VR Ukrainy. Retrieved from: https://zakon.rada.gov.ua/laws/show/z0750-99 [In Ukrainian].

14. Poriadok vyznachennia otsinochnoi vartosti obiektiv prava intelektualnoi vlasnosti, shcho perebuvaiut u derzhavnii vlasnosti abo buly stvoreni (prydbani) za derzhavni koshty, z metoyu zarakhuvannia na bukhhalterskyi oblik, zatverdzhenyi Nakazom Fondu derzhavnoho maina vid 13.12.2005 r. \# 3162 (zi zminamy) [The procedure for determining the appraised value of state-owned intellectual property or created (acquired) by state funds for the purpose of crediting for accounting, approved by the Order of the State Property Fund on 31.12.2005, No. 3162]. Baza danykh "Zakonodavstvo Ukrainy". VR Ukrainy. Retrieved from: https://zakon.rada.gov.ua/laws/show/z047906 [In Ukrainian].

15. Pro zatverdzhennia Natsionalnoho standartu \# 4 Ocinka mainovykh prav intelektualnoi vlasnosti: Postanova Kabinetu Ministriv Ukrainy vid 03.10.2007 r. \# 1185 (zi zminamy) [On approval of the National Standard No. 4 Valuation of property rights of intellectual property: Resolution of the Cabinet of Ministers of Ukraine dated 03.10.2007, No. 1185]. Baza danykh "Zakonodavstvo Ukrainy". VR Ukrainy. Retrieved from: https://zakon.rada.gov.ua/laws/show/1185-2007-\%D0\%BF [In Ukrainian]. 
16. Pro zatverdzhennia Natsionalnoho standartu \# 1 Zahalni zasady otsinky maina i mainohvykh prav: Postanova Kabinetu Ministriv Ukrainy vid 10.09.2003 r. \# 1440 (zi zminamy) [On approval of the National Standard No. 1 General principles of property and property rights valuation: Resolution of the Cabinet of Ministers of Ukraine dated 10.09.2003, No. 1440]. Baza danykh "Zakonodavstvo Ukrainy". VR Ukrainy. Retrieved from: https://zakon.rada.gov.ua/laws/show/1440-2003-\%D0\%BF [In Ukrainian].

17. Rudnyk-Ivashchenko, O.I. \& Kropyvko, V.S. (2013). Otsinka vartosti sortu roslyn yak obiektu intelektualnoi vlasnosti [Estimating value of a plant variety as an intellectual property object]. Visnyk Tsentru naukovoho zabezpechennia APV Kharkivskoi oblasti, 14, pp. 287-294 [In Ukrainian].

18. Pidlisetskyi, H.M., Lisniak, V.H., Zhuk, V.M., Mohylova, M.M., et al. (2012). Standarty z otsinky ta otsinochnoi diialnosti $v$ ahropromyslovomu kompleksi Ukrainy [Standards for evaluation and evaluation activity in the agro-industrial complex of Ukraine]. Kyiv: "VSEO" [In Ukrainian].

19. Standartyi otsenki RICS [RICS assessment standards]. (2011). Moscow: Alpina Pablisherz [In Russian].

20. Pidlisetskyi, H.M. (Ed.) (2001). Formuvannia rynkiv materialnykh resursiv APK [Formation of markets for agricultural materials resources]. Kyiv: NNTs “IAE” [In Ukrainian].

Захарчук О.В., Мацибора Т.В., Нечитайло В.В., Антоненко В.О. Оцінка нематеріальних активів у сільському госnодарствi

Mета статmi - розглянути погляди щодо методичних підходів до оцінки нематеріальних активів через призму розвитку інтелектуальної власності та капіталізації аграрних підприємств у сучасних умовах.

Методика дослідження. У процесі дослідження використано діалектичний метод наукового пізнання, аналізу й синтезу, системного узагальнення (узагальнення підходів до оцінки нематеріальних активів і формування висновків), методи абстрагування, порівняння (при оцінці первісної та справедливої вартості сорту рослин).

Результати дослідження. Узагальнено підходи до оцінки нематеріальних активів через призму розвитку інтелектуальної власності та капіталізації аграрних підприємств. Обгрунтовано методику оцінки вартості сорту рослин. Запропонований метод визначення первісної і справедливої вартості сорту рослин ґрунтується на основі встановлення рейтингу кожного об'єкта.

Елементи наукової новизни. На основі узагальнення підходів до оцінки нематеріальних активів запропоновано методику оцінки вартості сорту рослин через встановлення рейтингу сорту, його обсягу, терміну використання й узгоджених відсотків винагороди (роялті).

Практична значущість. Висновки, пропозиції та практичні рекомендації, а також авторська методика оцінки вартості сорту рослин при практичному їх застосуванні можуть суттєво змінити відносини між селекціонерами, власниками сортів та виробниками насіння і садивного матеріалу, забезпечити справедливі фінансові розрахунки, що надасть новий поштовх для розвитку національної селекції. Рис.: 3. Бібліогр.: 20.

Ключові слова: нематеріальні активи; нематеріальні активи в сільському господарстві; оцінка нематеріальних активів; ідентифіковані матеріальні активи; неідентифіковані матеріальні активи; інтелектуальна власність; об'єкт інтелектуальної власності; оцінка вартості сорту рослин.

Захарчук Олександр Васильович - доктор економічних наук, старший науковий співробітник, завідувач відділу інвестиційного та матеріально-технічного забезпечення, Національний науковий центр «Інститут аграрної економіки» (М. Київ, вул. Героїв Оборони, 10)

E-mail: zahar-s@ukr.net

ORCID iD https://orcid.org/0000-0002-1734-1130

Мацибора Тетяна Вікторівна - кандидат економічних наук, старший науковий співробітник, провідний науковий співробітник відділу інвестиційного та матеріально-технічного забезпечення, Національний науковий центр «Інститут аграрної економіки» (м. Київ, вул. Героїв Оборони, 10)

E-mail: tatyk@ukr.net

Нечитайло Вероніка Володимирівна - кандидат економічних наук, старший науковий співробітник відділу інвестиційного та матеріально-технічного забезпечення, Національний науковий центр «Інститут аграрної економіки» (м. Київ, вул. Героїв Оборони, 10)

E-mail: nika.nechytailo@gmail.com

Антоненко Василь Олександрович - аспірант відділу інвестиційного та матеріально-технічного забезпечення, Національний науковий центр «Інститут аграрної економіки» (м. Київ, вул. Героїв Оборони, 10)

E-mail: vasyl.antonenko@minagro.gov.ua

Захарчук А.В., Мацибора Т.В., Нечитайло В.В., Антоненко В.А. Оченка нематериальных активов в сельском хозяйстве

Цель статьи - рассмотреть взгляды относительно методических подходов к оченке нематериальных активов сквозь призму развития интеллектуальной собственности и капитализации аграрных предприятий в современных условиях.

Методика исследования. В процессе исследования использованы диалектический метод научного познания, анализа и синтеза, системного обобщения (обобщение подходов к оценке нематериальных активов и формирования выводов), методы абстрагирования, сравнения (при оценке первоначальной и справедливой стоимости сорта растений).

Результаты исследования. Обобщены подходы к оценке нематериальных активов сквозь призму развития интеллектуальной собственности и капитализации аграрных предприятий. Обоснована методика оценки стоимости сорта рас- 
тений. Предложенный метод определения первоначальной и справедливой стоимости сорта растений базируется на основе установления рейтинга каждого объекта.

Элементы научной новизны. На основе обобщения подходов к оценке нематериальных активов предложена методика оценки стоимости сорта растений через определение рейтинга сорта, его объема и срока использования, а также согласованных процентов вознаграждения (роялти).

Практическая значимость. Выводы, предложения и практические рекомендации, а также авторская методика оценки стоимости сорта растений при практическом их применении могут существенно изменить отношения между селекционерами, владельцами сортов и производителями семян и посадочного материала, обеспечить справедливые финансовые расчеты, что даст новый толчок для развития национальной селекции. Илл.: 3. Библиогр.: 20.

Ключевые слова: нематериальные активы; нематериальные активы в сельском хозяйстве; оценка нематериальных активов; идентифицированные материальные активы; неидентифицированные материальные активы; интеллектуальная собственность; объект интеллектуальной собственности; оценка стоимости сорта растений.

Захарчук Александр Васильевич - доктор экономических наук, старший научный сотрудник, заведующий отделом инвестиционного и материально-технического обеспечения, Национальный научный центр «Институт аграрной экономики» (г. Киев, ул. Героев Обороны, 10)

E-mail: zahar-s@ukr.net

ORCID iD https://orcid.org/0000-0002-1734-1130

Мацибора Татьяна Викторовна - кандидат экономических наук, старший научный сотрудник, ведущий научный сотрудник отдела инвестиционного и материально-технического обеспечения, Национальный научный центр «Институт аграрной экономики» (г. Киев, ул. Героев Обороны, 10)

E-mail: tatyk@ukr.net

Нечитайло Вероника Владимировна - кандидат экономических наук, старший научный сотрудник отдела инвестиционного и материально-технического обеспечения, Национальный научный центр «Институт аграрной экономики» (г. Киев, ул. Героев Обороны, 10)

E-mail: nika.nechytailo@gmail.com

Антоненко Василий Александрович - аспирант отдела инвестиционного и материально-технического обеспечения, Национальный научный центр «Институт аграрной экономики» (г. Киев, ул. Героев Обороны, 10)

E-mail: vasyl.antonenko@minagro.gov.ua

The article has been received 04.09.2019

Revision: 09.09.2019

Бібліографічний опис для цитування:

Zakharchuk O. V., Matsybora T. V., Nechytailo V. V., Antonenko V. O. Valuation of non-material assets in agriculture. Економіка АПК. 2019. № 8. С. 40 - 51.

\section{Затверджено перелік українських потужностей з виробництва яловичини для експорту на китайський ринок}

За результатами першої міжнародної офіційної зустрічі Міністра розвитку економіки, торгівлі та сільського господарства Тимофія Милованова з Віце-міністром делегації Генеральної митної адміністрації Китайської Народної Республіки (GACC) на чолі з Віце-міністром п. Лі Гуо українські потужності з виробництва яловичини нарешті отримали право експорту до КНР.

Китай затвердив перелік українських потужностей з виробництва замороженої яловичини для експорту її в країну. Наразі до зазначеного переліку внесені три потужності з виробництва замороженого м'яса яловичини, але процес триває, продовжують надходити заявки на відкриття китайського ринку для інших українських виробників.

Це рішення стало результатом роботи інспекційної місії GACC, яка перебувала в Україні 3-10 червня 2019 р. з метою оцінки системи державного контролю за виробництвом м'яса великої рогатої худоби.

Можливість експорту української яловичини на китайський ринок вивчалася ще з 2016 року. За цей час відбулося ряд переговорів, зустрічей, місій і візитів представників Держпродспоживслужби, українського і китайського посольств, компетентного органу КНР, урядових делегацій, зокрема Мінагрополітики та Мінекономрозвитку.

Активізації співробітництва слугувало перебування компетентного органу Китаю в Україні у квітні 2017 р. з метою оцінювання вітчизняної системи державного контролю за безпечністю харчових продуктів у частині виробництва яловичини. За їі результатами в Києві у травні 2017 р. Держпродспоживслужба та Генеральна адміністрація нагляду за якістю, інспекції та карантину KHP (AQSIQ) підписали Протокол інспекційних, карантинних та ветеринарно-санітарних вимог щодо експорту замороженої яловичини з України до Китайської Народної Республіки. Підписання протоколу свідчило про офіційне відкриття китайського ринку для української яловичини. Але для практичного виходу цієї вітчизняної продукції на китайський ринок українські підприємства повинні були пройти аудити компетентного органу КРН. Тепер із затвердженням списку українських підприємств, яким відкрито доступ до експорту яловичини до Китаю, і цей рубіж подолано.

Підприємства, які мають намір експортувати заморожену яловичину до КНР, повинні насамперед ознайомитися з вимогами цієї країни щодо експорту зазначеної продукції, розміщеними на сайті Держпродспоживслужби (рубрика «Міжнародне співробітництво» - «Вимоги країн світу»).

Прес-служба Мінекономіки 